Oleg Suberlyak and Volodymyr Skorokhoda

\title{
THE PECULIARITIES OF THE POLYVINYLPYRROLIDONE COPOLYMERS SYNTHESIS FOR CONTACT LENSES
}

\author{
Lviv Polytechnic National University, Lviv, Ukraine \\ 12, St.Bandera st., Lviv, 79013, Ukraine. \\ suberlak@polynet.Iviv.ua
}

Received: April 18, 2007

\begin{abstract}
The research results of the hydrogels synthesis rules on the basis of 2-hydroxyethylmethacrylatepolyvinylpyrrolidone copolymers and effective ways of adjusting of their proper-ties are given. Synthesized copolymers appeared to be effective materials for production of hydrophilic contact lenses.
\end{abstract}

Key words: hydrogel, polyvinylpyrrolidone, 2-hydroxyethylmethacrylate, contact lens.

\section{Introduction}

The intensive development of polymeric chemistry and technology has resulted in wide introduction of polymers in various areas of human activity, the special interest among which represents the use of polymers in medicine. At the early stages of biomedical polymers development they were only substitutes of already known polymers, later - as medicines, in the production of instrumentation, stomatological instruments and artificial organs of a human body. It should be noted, that the need for such polymers is huge and is growing every year. So, according to the data given by Prof. Atsymi Kadzyhiko, only in 2000, 150 thousand people of the globe needed synthetic bones and joints, 2.5 million required blood vessels, about 1 million people was in need of heart valves, 1.5 million - lungs, more than 1 million - kidneys. However, life puts forward the more and more difficult demands for polymeric materials that is why one of basic directions, the polymeric science is developing now, is the creation of such material system, which can completely reproduce biological functions of a living organism.

The basic demands to synthetic organs are absolute harmlessness for an organism, absence of cancerogenic or allergic influence, stability of properties in time etc. Besides, depending on specificity of that or other synthetic organ, the material should also meet many other specific requirements.

Besides mentioned above artificial organs, the mankind is in great need of ophthalmologic implants intraocular, treating and correctional contact lenses. The contact lenses are made in two modifications - solid and soft. Their well-known advantage is hyper permeability for an eye-water liquid and oxygen, the property which appreciably reduces a discomfort of lenses at use. In their turn, the soft contact lenses are made either from hydrogels, or from silicones. The silicone lenses have a hyper permeability for oxygen, but they moisten badly and are impenetrable for an eyewater liquid and are rather inconvenient for long using. Investigations carried out in the trend of the creation of long usage contact lenses are directed on the development of materials, which should have a necessary permeability for oxygen and eye-water liquid, as well as provide high optical and mechanical properties at minimum thickness and mass of a lens.

\section{Results and Discussion}

The Department of Chemical Technology and Processing of Plastics of Lviv Polytechnic National University has been carrying out investigations in the field of synthesis and application of medical polymers, including ophthalmologic ones, for more than 25 years. Mainly, these investigations are directed on the synthesis of new and modification of existing polymers. After the long approbation period, polyvinylpyrrolidone (PVP) has been chosen as the base starting product. Uniqueness of PVP properties and its application are caused by its structure and physical-chemical properties - the presence of carbamatic group promotes high selective - sorption properties, complex formation with iodine and other inorganic and organic compounds, formation of and ionic form of macromolecules in an aqueous medium [1]: 


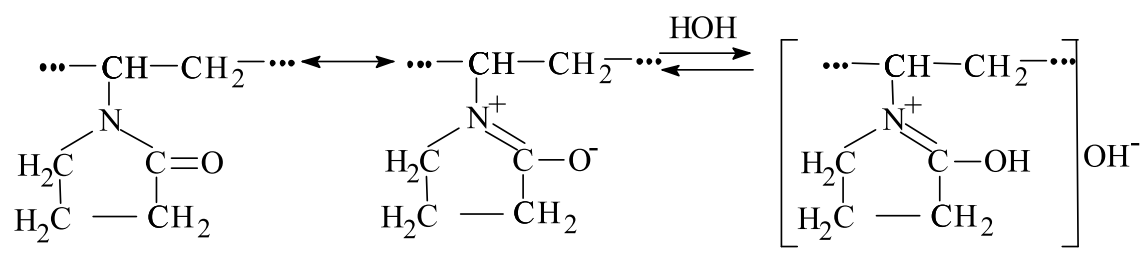

Besides, PVP is non-toxic and biologically compatible, and it is successfully applied in medicine as a substitute of a blood plasma. All this allows speaking about high functional activity which will be shown by polymers and PVP polymers including their contact with organism tissues.

The synthesis of PVP copolymers is developing in two directions: in the first statistical copolymers of Nvinylpyrrolidone with hydrophylic or hydrophobic monomers (as a rule, acrylic) are received; in the second attached copolymers received on the basis of PVP containing monomer compositions. In most cases these<smiles>CCC(C)N(CC)C(=O)OCCO</smiles>

It plays a role of initiating system even without traditional peroxide initiators or N-compounds. In this copolymers are rarely structured and swell to some extent in water and organic solvents. According to their properties, block and graft copolymers are similar, but as for adaptability to manufacture polymer - monomer compositions and attached copolymers are more attractive. When using PVP-monomer reaction mixtures for the synthesis of copolymers positive effect of the complex formation with charge transfer (CCT) between monomer (2- hydroxyethylmethacrylate (HEMA)) and polymeric matrix was fixed [2]:

case initiation occurs according to the following scheme:

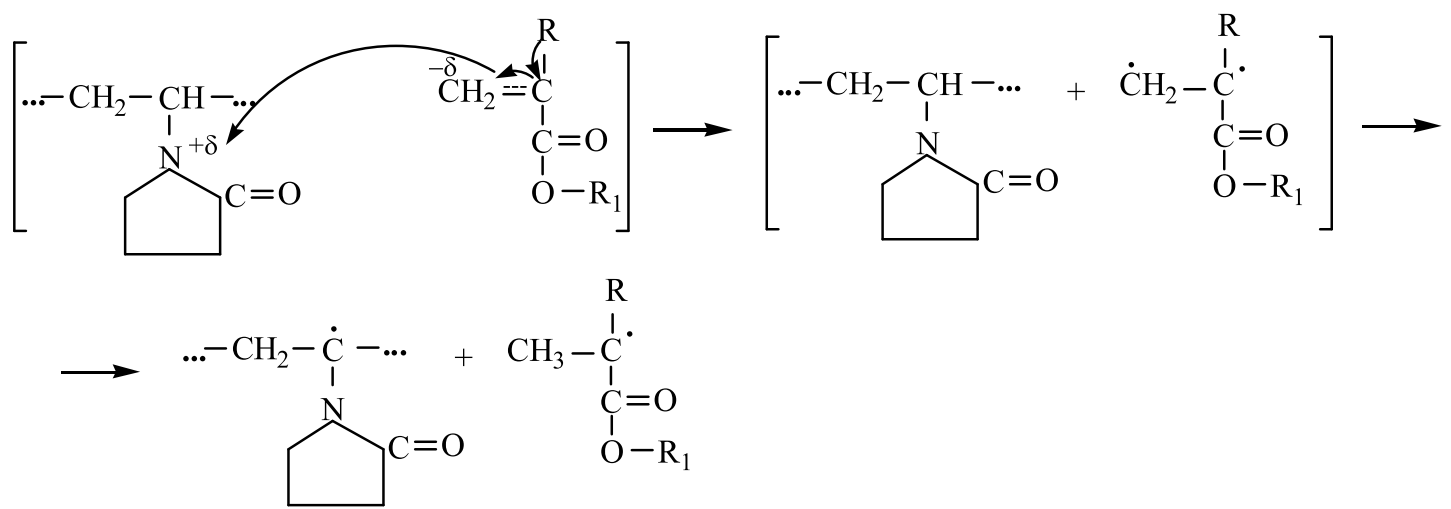

As the result, the formation of various finished products (homo- and graft (co)polymers) is possible.

By means of polymerization research of widely known HEMA in a composition with PVP, another CCT effect was found out. It consists in the interconnection between constant of complex formation $\mathrm{K}_{\mathrm{C}}$ and structural parameters of copolymer grid and their properties (Table 1).

Table 1

Dependence of PVP inoculation efficiency (f) and molecular weight of a grid internodal fragment $\left(M_{f}\right)$ on a constant complexformation $\left(K_{C}\right)$ in the system PVP-HEMA-dissolvent

\begin{tabular}{|c|c|c|c|c|}
\hline № & $\mathrm{K}_{\mathrm{C}}, \mathrm{dm}^{3} /$ mole & $\mathrm{M}_{\mathrm{f}}, \mathrm{kg} /$ mole & $\mathrm{f}, \%$ & $\begin{array}{c}\text { PVP content in } \\
\text { copolymers, } \%\end{array}$ \\
\hline 1 & 0.28 & 24 & 87 & 20 \\
2 & 0.13 & 34 & 60 & 30 \\
3 & 0.05 & 46 & 47 & 45 \\
4 & $\sim 0$ & 64 & 35 & 60 \\
\hline
\end{tabular}


By means of those two revealed effects, we have developed ways of regulated synthesis of PVP copolymers with HEMA and dimethacrylate, which are characterized by high sorption (Table 2) and selective diffusive properties (Table 4). Thus, it should be noted, that owing to a sorption of a considerable quantity of water, most of them are subjected to essential morphological changes because of physical transferring from glass figurative in highly elastic condition. This makes possible for them to gain new physical properties and reach high compatibility with organism tissues.

Sorption properties of synthesized copolymers

\begin{tabular}{|c|c|c|c|}
\hline (Co)polymer & Equilibrium water content, $\%$ & $\begin{array}{c}\text { Sorption of } \\
\text { heparin, } \\
10^{-3} \mathrm{u} / \mathrm{m}^{2}\end{array}$ & $\begin{array}{c}\text { Sorption of } \\
\mathrm{pASA}, 10^{3} \mathrm{~g} / \mathrm{g}\end{array}$ \\
\hline $\begin{array}{c}\text { polyHEMA } \\
\text { PVP-graft-polyHEMA } \\
\text { polyTGM-3** }\end{array}$ & 38 & 115 & 12 \\
PVP-graft-polyTGM-3 & $48 \ldots 60$ & $500 \ldots 600$ & $14 \ldots 17$ \\
Notes: * p-aminosalicylic acid \\
$* *$ TGM-3 - triethyleneglycoldimethacrylate
\end{tabular}

It should be noted, that during water sorption optical properties of copolymers change differently depending on structure. The conditions of copolymers synthesis and their compositions have been defined, which are characterized during hydration by stability of optical properties. This enables to utilize them as starting materials for optical correctional contact lenses. At the same time, large attention was attached to the dependence of physical-mechanical characteristics of the obtained materials on synthesis conditions and copolymers composition (Table 3).

Physical-mechanical properties of polymers in a hydrated condition

\begin{tabular}{|c|c|c|c|c|c|}
\hline \multirow{2}{*}{ № } & \multicolumn{3}{|c|}{ Composition content for hydrogel synthesis, mass $\mathrm{p}$. } & \multirow{2}{*}{$\begin{array}{c}\sigma, \\
\mathrm{MPa} \\
\end{array}$} & \multirow{2}{*}{$\begin{array}{l}\varepsilon, \\
\%\end{array}$} \\
\hline & HEMA & PVP & TGM-3 & & \\
\hline 1 . & 100 & - & - & 0.53 & 160 \\
\hline 2. & 80 & 20 & - & 0.40 & 235 \\
\hline 3. & 80 & 20 & 2 & 0.30 & 195 \\
\hline 4. & 80 & 20 & 5 & 0.25 & 160 \\
\hline 5. & 80 & 20 & 10 & 0.18 & 130 \\
\hline 8. & 70 & 30 & - & 0.31 & 270 \\
\hline 9. & 50 & 50 & - & 0.22 & 295 \\
\hline
\end{tabular}

Note: $\mathrm{s}$ - tensile strength, e - relative elongation under rupture

Sorption-diffusion properties of (co)polymers

\begin{tabular}{|c|c|c|c|c|c|c|c|c|c|}
\hline \multirow[t]{2}{*}{ № } & \multicolumn{4}{|c|}{$\begin{array}{c}\text { Composition content for hydrogel } \\
\text { synthesis mass } p \text {. }\end{array}$} & \multirow{2}{*}{$\begin{array}{l}\mathrm{W}, \\
\%\end{array}$} & \multirow{2}{*}{$\begin{array}{c}\text { Water permeability } \\
\mathrm{K} \cdot 10^{4}, \\
\mathrm{~m}^{3} \cdot \mathrm{m}^{-2} \cdot \mathrm{h}^{-1}\end{array}$} & \multicolumn{3}{|c|}{$\begin{array}{l}\text { Coefficient of permeability, } \\
\text { mole } \cdot \mathrm{m}^{-2} \cdot \mathrm{h}^{-1}\end{array}$} \\
\hline & HEMA & PVP & $\mathrm{H}_{2} \mathrm{O}$ & $\mathrm{AD}$ & & & $\mathrm{NaCl}$ & Urea & Saccharose \\
\hline 1. & 100 & - & 100 & - & 38 & 5.1 & 80 & 13 & 5 \\
\hline 2. & 80 & 20 & 100 & - & 48 & 52.3 & 181 & 36 & 14 \\
\hline 3. & 80 & 20 & 95 & 5 & - & 54.6 & 193 & - & - \\
\hline 4. & 80 & 20 & 90 & 10 & 47 & 56.5 & 212 & - & - \\
\hline 5. & 80 & 20 & 80 & 20 & 47 & 62.4 & 240 & - & - \\
\hline $6^{*}$. & 80 & 20 & 200 & - & 55 & 74.2 & 234 & 59 & 30 \\
\hline $7^{*}$. & 80 & 20 & 300 & - & 61 & 90.3 & 263 & 60 & 31 \\
\hline 8. & 70 & 30 & 100 & - & 53 & 71.4 & 232 & 59 & 30 \\
\hline 9. & 50 & 50 & 100 & - & 61 & 102.1 & 274 & 65 & 33 \\
\hline
\end{tabular}

Notes: AD - aprotic dissolvent, W- water conent. coefficient of permeability of light for polymers of composition $1-5,8,9-90 \ldots 96 \%$.

* - opaque polymers 
The application bifunctional oligomer products of a type TGM-3 allows to increase essentially hardness of hydrogels, however, in such a way the elasticity of materials is reduced, that is caused by considerable influence of TGM-3 on the copolymers grid density.

The physical-mechanical properties of copolymers in equilibrium - swollen a state can change within a wide range and the task of research was to define optically transparent compositions, which should provide necessary hardness and elasticity of materials. Thus the opportunity of obtaining materials with varying hardness and elasticity which are characterized by varying equilibrium water content or identical water content was found out.

At the same time, the synthesized copolymers differ not only by high sorption properties, but also by selective - diffusive properties during a dialysis of aqueous solutions (Table 4).

It is necessary to note, that the change of the structure and composition of copolymers may considerably influence the size of refraction index $n_{D}$. This was consequently used for optimization of copolymers composition for contact lenses. It allowed receiving correctional soft contact lenses [3] with the following operational properties (Table 5).

Table 5

The characteristics of a polymeric material for soft contact lenses

\begin{tabular}{|c|l|c|}
\hline № & \multicolumn{1}{|c|}{ Properties in hydrated condition } & $\begin{array}{c}\text { Parameter } \\
\text { meaning }\end{array}$ \\
\hline 1. & Absorption of water, \% & $50-52$ \\
2. & Oxygen permeability, $10^{10} \mathrm{~m}^{2} / \mathrm{sec}$ & 1.2 \\
3. & Water permeability, $10^{4} \mathrm{~m}^{3} \cdot \mathrm{m}^{-2} \cdot \mathrm{h}^{-1}$ & 52 \\
4. & NaCl permeability, mole $\cdot \mathrm{m}^{-2} \cdot \mathrm{h}^{-1}$ & 180 \\
5. & Toughness at a stretching, MPa & 0.4 \\
6. & Relative tensile elongation, \% & 250 \\
7. & Permeability of light, \% & 96 \\
\hline
\end{tabular}

As a result of increased oxygen permeability and high refraction index $n_{D}$ of lenses stand out for comfort at operation that allows wearing them on an eye for a long time without fatigability.

The carried out researches of synthesis and structure formation laws of PVP copolymers have also allowed to develop a material with increased elasticity properties in a hydrated condition, that enables to make from it ultra-thin contact lenses of new generation retaining high operational properties even at thickness of $0.04 \mathrm{~mm}$ [4].
Good permeability for series of substances, including medicinal solutions, compatibility with tissues and acceptability has caused use of the synthesized copolymers for medical ophthalmologic elements of the various forms

The comparative clinical tests about the state of eye-sight without correction are carried out. From 163 patients having an eye-sight without correction less 0.1 , after correction by means of contact lenses an acuteness of eye-sight has increased for more than in $80 \%$ and was equal to $0.85-1.0$. The research of an epithelial integument of a cornea condition carried out in a various terms after acclimatization at all the patients has shown, that infringement of integrity crates membranes of an epithelium of a cornea does not occur. And only at 6 patients after long continuous application of lenses (more than 3 days) was observed a mild epithelium reddening.

\section{Conclusion}

Thus, copolymers developed on the basis of compositions of methacrylic esters with polyvinylpyrrolidone turned out to be suitable for the obtaining of medical and correcting contact lenses of a new generation with high operating properties.

\section{References}

[1] Crassous G. and Jozephovich M.: Biomaterials, 1984, 5 (3), 153.

[2] Suberlyak O., Skorokhoda V. and Levitsky V.: Ukr.Polym.J., 1995, 5,177.

[3] Suberljak O., Skorokhoda V., Benedyk N. and Jaremkevych S. Sposib oderzhannja gidrofil'nyh polimeriv. Patent Ukrainy N37936A 15.05.2001.

[4] Suberljak O., Skorokhoda V. and Levytskyj V.: Khim. prom. Ukrajiny, 2002, 4, 19.

\section{ОСОБЛИВОСТІ СИНТЕЗУ КОПОЛІМЕРІВ ПОЛІВІНІЛПІРОЛІДОНУ ДЛЯ КОНТАКТНИХ ЛІНЗ}

Анотація. Приведені результати досліджень закономірностей синтезу гідрогелів на основі кополімерів 2гідроксіетилметакрилату з полівінілпіролідоном та ефективні иляхи регулювання їх властивостей. Синтезовані кополімери виявились ефективними матеріалами для виробництва гідрофільних контактних лінз.

Ключові слова: гідрогель, полівінілпіролідон, 2-гідроксіетилметакрилат, контактні лінзи. 